特集：自己抗体

総説

抗 MDA5（melanoma differentiation-associated gene 5）抗体と皮膚筋炎 ·急速進行性間質性肺炎

中嶋 蘭*1, 三 森 経 世*2

\title{
Anti-MDA5 (melanoma differentiation-associated gene 5) antibody and dermatomyositis with rapidly progressive interstitial pneumonia
}

\author{
Ran NAKASHIMA*1 and Tsuneyo MIMORI*2 \\ ${ }^{*}$ Department of Rheumatology and Clinical Immunology, Kyoto University Hospital \\ ${ }^{*}$ Department of Rheumatology and Clinical Immunology, Kyoto University Graduate School of Medicine
}

(Accepted February 14, 2013)

summary

Anti-MDA5 antibody is one of the dermatomyositis-specific autoantibodies and anti-MDA5-potsitive patients show characteristic clinical features, such as hypomyositis, high prevalence of acute/subacute interstitial pneumonia (A/ SIP) with poor prognosis, hyperferritinemia and elevated hepatobiliary enzyme. We found that serum IL-6, IL-18, M-CSF and IL-10 were significantly higher and serum IL-12 and IL-22 were significantly lower in anti-MDA5-positive patients than in anti-MDA5-negative patients before treatment. Taking together these serological findings, we hypothesized that monocyte and macrophage activation may underlie in the pathophysiology of anti-MDA5-positive patients. They rarely survive after they become to need oxygenation, and so need to be treated as soon as possible once the diagnosis has been made. Intensive regimen of combined immunosuppressive therapy (high-dose corticosteroids, oral cyclosporin and intravenous cyclophosphamide (IVCY, 900-1000 mg/m² in every other week)) improved the survival rate of anti-MDA5-positive patients. Especially, the serum ferritin levels tended to go down about 14 days after IVCY, suggesting that IVCY might be a key drug in the treatment of anti-MDA5-positive A/SIP patients.

Key words_anti-MDA5 antibody; dermatomyositis; interstitial pneumonia; ferritin; macrophage

抄 録

抗 MDA5 抗体は皮膚筋炎特異的抗体であり，同抗体陽性例は筋症状が少なく，高率に急速進行性間質性肺炎を 併発し予後不良であること，高フェリチン血症・肝胆道系酵素上昇を伴うなど特徵的な臨床像を呈する.抗 MDA5 抗体陽性患者と陰性皮膚筋炎患者の治療前血清サイトカインを比較したところ前者では有意に IL-6, IL18，M-CSF，IL-10 が高值を示し，IL-12，IL-22 は低值を示した。これらのことから，抗 MDA5 抗体陽性例にお いては単球・マクロファージの異常活性化が病態の背景に存在すると考えている. 抗 MDA5 抗体陽性例は一旦酸 素投与が必要な呼吸不全状態になると極めて救命率が低いため，診断後可及的速やかに治療介入が必要であると考 えられる，ステロイド大量療法・シクロスポリン内服・シクロホスファミド間歇静注療法（IVCY）の 3 剂を併用 した強力免疫抑制レジメンを用いることで，同抗体陽性例の予後が改善した．特に疾患活動性を反映することが報 告されている血清フェリチン值は，IVCY 投与約 2 週後に低下する傾向を認め，IVCY が同抗体陽性例の治療に㧍 いてキードラッグとなることが示唆された.

\footnotetext{
*1京都大学医学部附属病院 免疫·膠原病内科
}

$*_{2}$ 京都大学大学院医学研究科臨床免疫学 


\section{はじめに}

自己免疫疾患では様々な自己抗体が検出され, 疾 患の診断のみならず，分類・治療方針の決定 ·予後 予測においても有用な指標となる。 また病因・病態 を解く鍵となることもしばしばある．近年筋症状の ない皮膚筋炎に特異的な自己抗体として抗 CADM140 抗体が見いだされ，その対応抗原が MDA5 で あることが示された ${ }^{123)}$. MDA5 は細胞質内でウイ ルスRNA を認識し，下流にシグナルを伝えて 1 型 インターフェロン産生を誘導するという, 自然免疫 において重要な役割を担う分子である4).

抗 MDA5 抗体陽性例は特徵的な臨床像を呈する ことが近年報告されてきており，とくに急速進行性 間質性肺炎 (acute/subacute interstitial pneumonia ; A/SIP）を併発し, 生存率が低いことが知られてい る3).しかしその病態は未だ明らかでなく, エビデ ンスのある治療法も確立していない。本稿では抗 MDA5 抗体陽性例に抢ける血清サイトカインの特 徵をもとに病態の仮説を立て, 有望な治療法につい て概説する.

\section{I. 抗 CADM-140（MDA5）抗体の特徵}

定型的な DM の皮疹（ゴットロン徵候，ヘリオ トロープ疹）があるものの筋炎所見を認めない症 例は amyopathic DM (ADM) と呼ばれ, 臨床的に 筋症状がないものの検査所見で筋炎所見を認めるも の (hypomyopathic DM) も含めて clinically ADM (CADM) と総称される. CADM は日本人におい て治療抵抗性の急速進行性間質性肺炎を併発する頻 度が高く，予後不良の病態として多くの報告がなさ

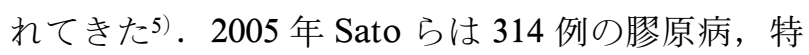
発性間質性肺炎患者と健常人の血清に対し, タンパ ク免疫沈降法による自己抗体のスクリーニングを行 い, CADM 患者 15 例中 8 例に $140 \mathrm{kD}$ タンパクを 沈降する自己抗体を見出し，抗 CADM-140 抗体と 命名した1). 同抗体陽性患者は全例 CADM であり,

A/SIP を高率に併発することを報告した。その後 同抗体の対応抗原が melanoma differentiation-associated gene 5 (MDA5) と同定された2,3).この分 子は細胞内でピコルナウイルスなどの RNA を認識 し I 型インターフェロン産生を誘導して自然免疫で 重要な役割を果たすことが知られており4)，PM/ DM の発症にコクサッキーウイルス感染との関連が 以前から報告されていることからも興味深いもので

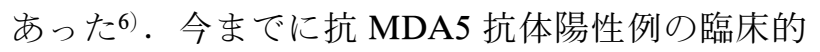
特徵についてはアジアを中心に報告されてきてお り, 皮膚筋炎の約 $15 \%$ に認め, 筋炎所見が少な く, 血清フェリチンや肝胆道系酵素が高值を示す頻 度が有意に高いこと, また IPを高頻度に併発し (約 95\%)，特に A/SIP を併発し (50〜70\%) 呼吸 不全で死亡する頻度が高いことなどが報告されてい る3,7,8). 一方, 欧米人の集団におけるコホートでは IP の頻度は $67 \%, \mathrm{~A} / \mathrm{SIP}$ は $22 \%$ と低く, 人種差が 認められる9).さらに血清フェリチン值は抗 MDA5 抗体陽性例の間質性肺炎の疾患活動性と相関するこ とも示唆されている3,10).

抗 MDA5 抗体陽性例に抢ける間質性肺炎の初診 時画像パターンとしては「下肺野の浸潤影もしくは スリガラス陰影」や「ランダムなスリガラス陰影」 を呈する頻度が高く, 反対に「小葉内網状影」を呈 することがないのが特徴であるという報告があ $\eta^{11)}$, 前述の臨床 · 血清学的特徵とともに抗 MDA5 抗体の存在を予測する参考所見になると考 えられる，今後さらなる症例を集めた解析が望まれ る.

\section{II. 抗 MDA5 抗体陽性例の病態}

前述のように抗 MDA5 抗体陽性例では肝胆道系 酵素上昇・高フェリチン血症を呈するとともに, 筆 者らの予備的な検討では血球減少を来す頻度も高い ことからマクロファージ活性化状態が同抗体陽性例 の病態に関連している可能性があると考えた。 そこ で治療前患者血清を用いて同抗体陽性例 $(n=23)$ と陰性 DM 例（ $\mathrm{n}=19 ）$ のサイトカイン濃度を比較 したところ, 血清 IL-6, IL-18, M-CSF, IL-10 は 同抗体陽性例の方が陰性例よりも有意に高值を示し, IL-12，IL-22 は有意に低值を示した（表 1).また， Gono らは抗 MDA5 抗体陽性例のうち生存例にお

表 1 DM 患者の初診時血清サイトカイン濃度比較

\begin{tabular}{cccc}
\hline \hline & $\begin{array}{c}\text { MDA5 抗体 } \\
(+) \\
(\mathrm{pg} / \mathrm{mL})\end{array}$ & $\begin{array}{c}\text { 抗 MDA5 抗体 } \\
(-) \\
(\mathrm{pg} / \mathrm{mL})\end{array}$ & $\mathrm{p}$ 值 \\
\hline $\mathrm{IL}-6$ & $17.8 \pm 12.1$ & $10.1 \pm 16.4$ & 0.001 \\
$\mathrm{IL}-18$ & $751.0 \pm 303.5$ & $658.0 \pm 730.6$ & 0.0083 \\
$\mathrm{M}-\mathrm{CSF}$ & $2800.2 \pm 1802.1$ & $1362.1 \pm 1200.2$ & $<0.001$ \\
$\mathrm{IL}-10$ & $20.5 \pm 61.1$ & $1.8 \pm 1.1$ & $<0.0001$ \\
$\mathrm{IL}-12$ & $1.1 \pm 0.9$ & $2.6 \pm 0.5$ & $<0.0001$ \\
$\mathrm{IL}-22$ & $36.8 \pm 47.2$ & $64.3 \pm 45.8$ & 0.003 \\
\hline
\end{tabular}

各平均 $\pm \mathrm{SD}$ Mann-Whitney $の \mathrm{U}$ 検定 
仮説

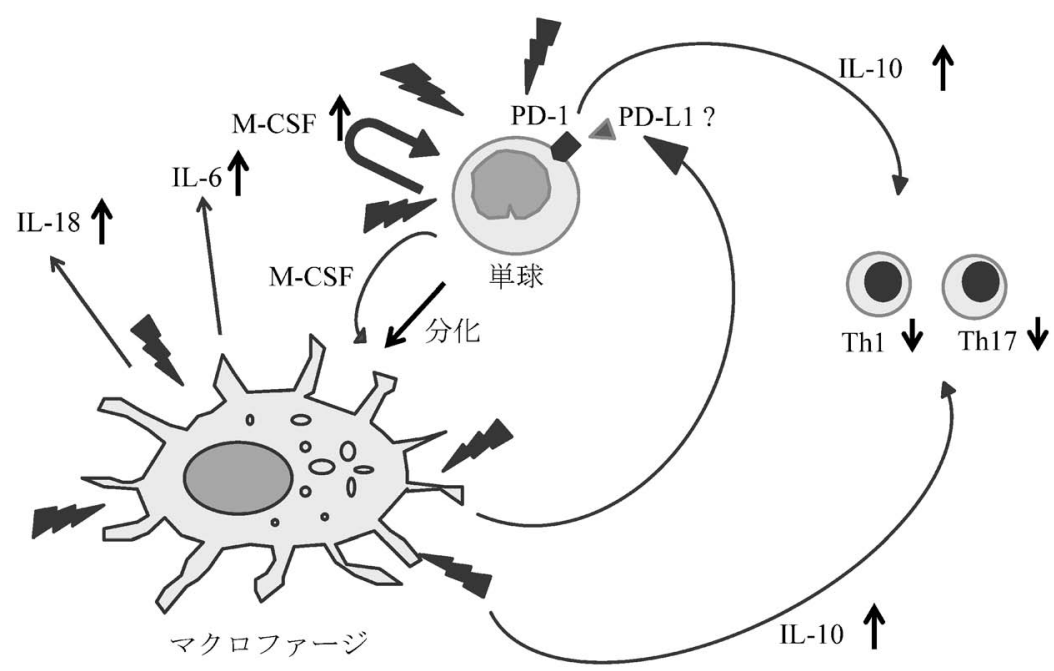

図 1

いては治療により血清 IL-18 の有意な低下を認め たことも報告している12).このような血清サイトカ インの特徵も踏まえて仮説を立てると，抗 MDA5 抗体陽性例においては単球・マクロファージ系が異 常活性化された状態が存在しており，それらの細胞 より M-CSF, IL-6, IL-18, IL-10 が高発現され, また IL-10 の作用により Th1 や Th17への分化が 抑制されることで IL-12, IL-22 といったサイトカ インの低下が生じているのかもしれない（図 1). 実際, 抗 MDA5 抗体陽性例の剖検組織に打いて 肺・肝 · 骨髄 ・脾蔵で CD68 陽性細胞が増加してい ることが報告されており，さらなる病理・病態組織 学的検討が必要である13).

\section{III. 抗 MDA5 抗体陽性例における予後因子}

抗 MDA5 抗体陽性例を生存例 $(\mathrm{n}=16)$ と死亡 例（ $\mathrm{n}=14 ）$ に分け臨床的背景を比較したところ （表 2)，死亡例は有意に高齢で DM 特異的皮疹発症 から IP 診断までの期間が有意に短かった。このこ とは IP が DM 発症とともに rush に生じてきてい ることを示唆するのかもしれない, また，治療の遅 れに関して IP 診断から治療開始までの期間に有意 差は認めなかったものの, 死亡例では治療介入が遅 い傾向にあり，呼吸不全に至った（酸素投与を必要 とした）症例では 15 例中 2 例しか救命できていな かった. 治療開始前フェリチン值は死亡例で高值を 示す傾向にあったが有意差は得られなかった。しか しステロイド以外の免疫抑制薬投与前のフェリチン
表 2 抗 MDA5 抗体 $(+)$ 例での生存例と死亡例の比較

\begin{tabular}{|c|c|c|c|}
\hline & \multicolumn{2}{|c|}{$\alpha \operatorname{MDA} 5(+)$ Pts } & \multirow{2}{*}{$\mathrm{p}$ values } \\
\hline & 生存 $\mathrm{n}=16$ & 死亡 $\mathrm{n}=14$ & \\
\hline 年齢 & $46.5 \pm 11.1$ & $59.4 \pm 9.7$ & $<0.01^{*}$ \\
\hline $\begin{array}{l}\mathrm{DM} \text { の皮疹発症か } \\
\text { ら IP 診断までの } \\
\text { 期間 (月) }\end{array}$ & $3.0 \pm 2.7$ & $1.1 \pm 1.0$ & $<0.01^{*}$ \\
\hline $\begin{array}{l}\text { IP 診断から治療 } \\
\text { 開始丈での期間 } \\
\text { (月) }\end{array}$ & $0.4 \pm 0.5$ & $0.7 \pm 0.7$ & $0.16^{*}$ \\
\hline 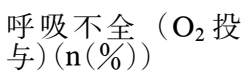 & $2(13 \%)$ & $13(93 \%)$ & $0.001^{* *}$ \\
\hline $\begin{array}{l}\text { 治療前血清フェリ } \\
\text { チン値 }(\mathrm{ng} / \mathrm{mL})\end{array}$ & $494 \pm 568$ & $909 \pm 757$ & $0.07^{*}$ \\
\hline $\begin{array}{l}\text { 免疫抑制薬投与前 } \\
\text { の血清フエリチン } \\
\text { 値 }(\mathrm{ng} / \mathrm{mL})\end{array}$ & $658 \pm 724$ & $3212 \pm 5334$ & $0.05^{*}$ \\
\hline
\end{tabular}

* Mann-Whitney U test, ${ }^{* *}$ Fisher's exact test

值で比較すると死亡例で有意に高值を示した。 Gono らも A/SIP を伴った抗 MDA5 抗体陽性例を 生存例（ $\mathrm{n}=11 ）$ と死亡例（ $\mathrm{n}=9$ ) に分け臨床特徵 を比較しているが，死亡例では初診時の $\mathrm{P} / \mathrm{F}$ ratio が有意に低く，A-aDO2 が高いこと，血清フェリ チン值も高いことを報告している12). 以上のことか ら，高齢・呼吸不全が予後不良因子であるととも に，診断後可及的早期にステロイドと免疫抑制薬を 併用した治療を行うことが予後改善につながる可能 性が考えられた。 


\section{IV. 抗 MDA5 抗体陽性例に対する治療}

DM の A/SIP に対しては初期治療の重要性が以 前から示唆されており14 16)，早期よりステロイド 大量に加えてシクロスポリン $(\mathrm{CyA})$ やタクロリム スを投与することが示唆されていた。 また Kameda らは 3 か月以内に進行した A/SIP 合併 DM 症例に おいては，ステロイドに加えて初期よりシクロホス ファミド間歇大量静注療法（IVCY） およびCyA を併用する方が，ステロイド＋免疫抑制薬 1 剂のみ に比較して救命率が改善したと報告している17).こ うした報告と当科での治療成功例における経験をも とに我々はステロイド大量療法・CyA I IVCYの 3 剂を組み合わせた多剤併用強力免疫抑制療法による レジメンを策定した（表 3 ）。このレジメンでは抗

\section{表 3 多剂併用強力免疫抑制療法}

1. ステロイド大量療法 初期量プレドニゾロン (PSL) 経口 $1 \mathrm{mg} / \mathrm{kg} / \mathrm{day} 4$ 週 間の後, 2-4 週毎に漸減

2. シクロスポリン (CyA) 開始量 : 3-5 mg/ $\mathrm{kg} /$ day. 内服後 2 時間值 $(\mathrm{C} 2)(700-1000 \mathrm{ng} / \mathrm{mL})$.

3. シクロホスファミド間歇静注療法 (IVCY)

1 6 回まで原則 : 2 週毎

初回投与量 : $500 \mathrm{mg} / \mathrm{m}^{2}$ 漸増する.

（10１4 日後の白血球の底值が 2000-2500/uL または IVCY 前後で白血球が半減する程度の投与量まで用量 を増加）

7 回目以降は $4 \sim 8$ 週毎 合計 $10 \sim 15$ 回続ける
MDA5 抗体陽性例全例に疾患診断時よりステロイ ド大量療法とともに，CyA の内服量を C2（服用 2 時間後血中濃度）が $700 \sim 1000 \mathrm{ng} / \mathrm{mL}$ に到達する ように調整し, IVCY は 6 回目までは 2 週間毎を原 則に高用量で投与するものである.このレジメンで 加療した群 $(\mathrm{n}=12)$ と従来法群（疾患が増悪する ごとに治療を強化していく step-up 療法）（n=14） の生存率を比較すると有意に前者の予後が良かった （6 ヶ月生存率 $75.0 \%$ vs 28.6\% ; p = 0.038)（図 2). また注目すべきことに, 生存では治療中血清フェリ チン值が疾患初期には常に上昇する傾向を認めるも のの, IVCY の約 2 週間後に低下するという経過を 繰り返しながら，数か月の期間を経て疾患活動性と ともに徐々に低下する傾向を認めた（図 3).この ことから，抗 MDA5 抗体陽性例の治療に拈いて IVCY がキードラッグとなる可能性が考えられた。

\section{おわりに}

近年, 特発性炎症性筋疾患（idiopathic inflammatory myopathy : IIM）では筋炎特異的自己抗体 (myositis-specific autoantibody : MSA) が次々と見 いだされ，それぞれの抗体陽性例の臨床プロファイ ルが明らかになるにつれ，IIMを自己抗体によって 分類する考え方が広まりつつある.さらに，今後は 自己抗体によって治療方針を決定することも可能に なると考えられる．抗 MDA5 抗体陽性例は IIM の 中では短期的予後が最も不良な群であり, 自己抗体 の検出意義が特に大きいと考えられる. 現在, 一般 臨床でルーチンに検出できる MSA は抗 Jo-1 抗体

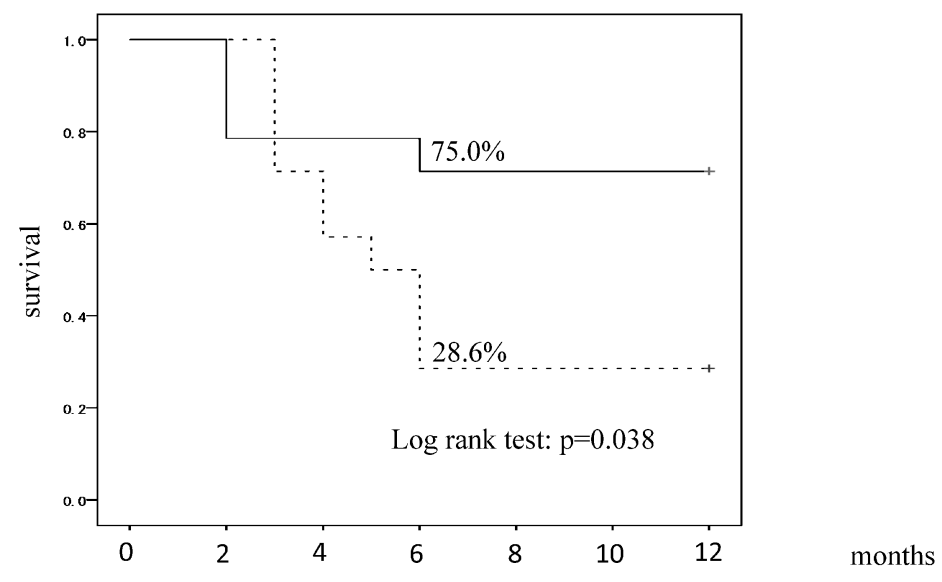

Intensive regimenを投与された症例 $(\mathrm{n}=12)$

従来法で病状に応じて治療を強化した症例 $(n=14)$

図 2 抗 MDA5 抗体 $(+)$ 例に打ける治療法による生存率の差 


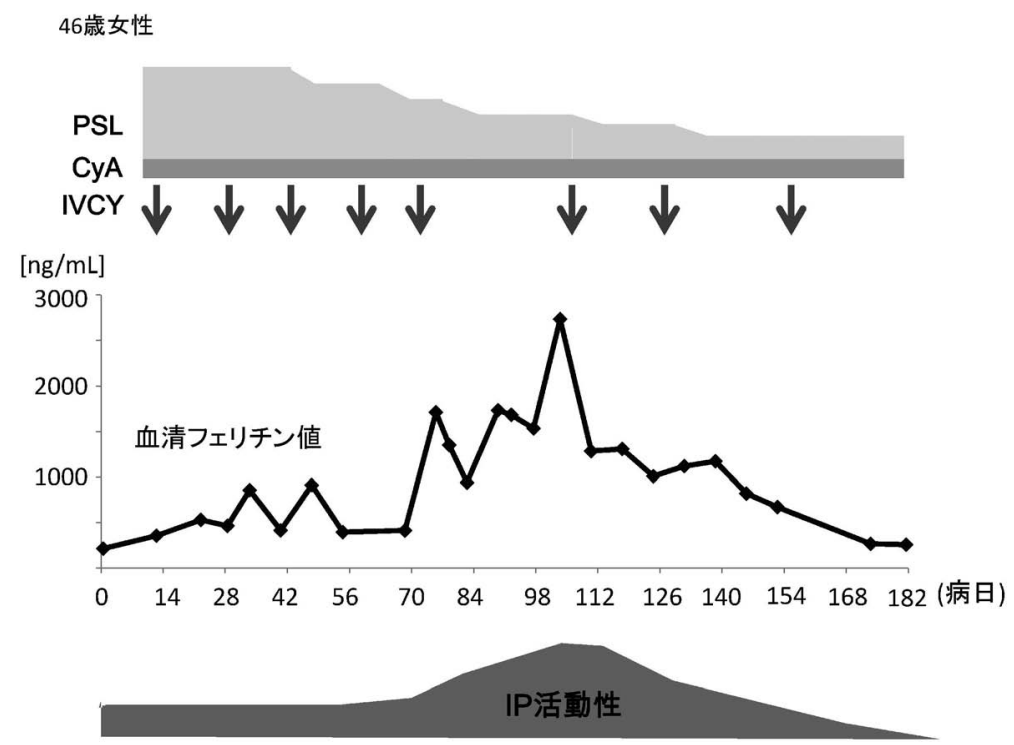

図 3 抗 MDA5 抗体陽性例の治療経過に打けるフェリチン值の推移

だけであるが，さらに多くの MSA を広く簡便に検 査できるようになることが望をれるとともに，疾患 グループごとに適正な治療法が行えるよう症例の蓄 積と病態研究が必要である.

\section{文献}

1) Sato $S$, Hirakata M, Kuwana M, et al. : Autoantibodies to a $140-\mathrm{kd}$ polypeptide, CADM140 , in Japanese patients with clinically amyopathic dermatomyositis. Arthritis Rheum. 52 : 1571-1576, 2005.

2) Sato S, Hoshino K, Satoh T, et al. : RNA helicase encoded by melanoma differentiationassociated gene 5 is a major autoantigen in patients with clinically amyopathic dermatomyositis : Association with rapidly progressive interstitial lung disease. Arthritis Rheum. 60 : 2193-2200, 2009.

3) Nakashima R, Imura $Y$, Kobayashi $S$, et al. : The RIG-I-like receptor IFIH1/MDA5 is a dermatomyositis-specific autoantigen identified by the anti-CADM-140 antibody. Rheumatology (Oxford). 49 : 433-440, 2010.

4) Kato H, Takeuchi O, Sato $S$, et al. : Differential roles of MDA5 and RIG-I helicases in the recognition of RNA viruses. Nature. 441 : 101105, 2006.

5) Nawata $Y$, Kurasawa K, Takabayashi K, et al. : Corticosteroid resistant interstitial pneumonitis in dermatomyositis/polymyositis: prediction and treatment with cyclosporine. J Rheumatol. 26 : 1527-1533, 1999.
6) Christensen ML, Pachman LM, Schneiderman $\mathrm{R}$, et al. : Prevalence of Coxsackie B virus antibodies in patients with juvenile dermatomyositis. Arthritis Rheum. 29 : 1365-1370, 1986.

7) Gono T, Kawaguchi $Y$, Satoh $T$, et al. : Clinical manifestation and prognostic factor in antimelanoma differentiation-associated gene 5 antibody-associated interstitial lung disease as a complication of dermatomyositis. Rheumatology (Oxfor). 49 : 1713-1719, 2010.

8) Hoshino K, Muro $Y$, Sugiura $K$, et al. : AntiMDA5 and anti-TIF1-gamma antibodies have clinical significance for patients with dermatomyositis. Rheumatology (Oxford). 49 : 1726-1733, 2010.

9) Fiorentino D, Chung L, Zwerner J, et al. : The mucocutaneous and systemic phenotype of dermatomyositis patients with antibodies to MDA5 (CADM-14) : a retrospective study. $J$ Am Acad Dermatol. 65 : 25-34, 2011.

10) Gono T, Kawaguchi Y, Ozeki E, et al. : Serum ferritin correlates with activity of anti-MDA5 antibody-associated acute interstitial lung disease as a complication of dermatomyositis. Mod Rheumatol. 21 : 223-237, 2011.

11) Tanizawa $K$, Handa $T$, Nakashima $R$, et al. : HRCT features of interstitial lung disease in dermatomyositis with anti-CADM-140 antibody. Respir Med. 105 : 1380-1387, 2011.

12) Gono $T$, Sato $S$, Kawaguchi $Y$, et al. : AntiMDA5 antibody, ferritin and IL-18 are useful for the evaluation of response to treatment in interstitial lung disease with anti-MDA5 an- 
tibody-positive dermatomyositis. Rheumatology (Oxford). 51 : 1563-1570, 2012.

13) Gono $\mathrm{T}$, Miyake $\mathrm{K}$, Kawaguchi $\mathrm{Y}$, et al. : Hyperferritinaemia and macrophage activation in a patient with interstitial lung disease with clinically amyopathic DM. Rheumatology (Oxford). 51 : 1336-1338, 2012.

14) Nagasaka K, Masayoshi H, Matsuto T. : Efficacy of combination treatment with cyclosporin A and corticosteroids for acute interstitial pneumonitits associated with dermatomyositis. Modern Rheumatology. 13 : 231-238, 2003.

15) Kotani T, Takeuchi T, Makino S, et al. : Combination with corticosteroids and cyclosporinA improves pulmonary function test results and chest HRCT findings in dermatomyositis patients with acute/subacute interstitial pneumonia. Clin Rheumatol. 30 : 1021-1028, 2011.

16) Ozawa $Y$, Kurosaka D, Yokoyama T, Tajima N. : [Therapeutic efficacy of cyclosporin A in four cases of amyopathic dermatomyositis with rapidly progressive interstitial pneumonia]. Ryumachi. 40 : 798-809, 2000.

17) Kameda $H$, Nagasawa $H$, Ogawa $H$, et al. : Combination therapy with corticosteroids, cyclosporin A, and intravenous pulse cyclophosphamide for acute/subacute interstitial pneumonia in patients with dermatomyositis. $J$ Rheumatol. 32 : 1719-1726, 2005. 